\title{
Study on Coordinated Development of Urbanization and Agricultural Land Resources
}

\author{
Shuyuan Xing ${ }^{1, a}$ \\ ${ }^{1}$ Business School of Xi'an International University, Xi'an, Shaanxi, 710077 \\ a email
}

Keywords: Urbanization, Agricultural Land Resources, Coordinated Development

\begin{abstract}
History shows that the process of urbanization and outside the presence of urbanization development and land very close relationship, how important aspects of the land use management will be the impact of the urbanization process. With the development of urbanization construction, land use management issues also will produce, such as intensive arable land serious waste and low efficiency, damage to the interests of farmers and other phenomena occur frequently, it is bound to affect sustainable urbanization development of. Therefore, to explore the process of urbanization and land use management measures, land management mechanism innovation, and comprehensively promote urbanization, has important practical significance.
\end{abstract}

\section{Introduction}

China is a developing country people will be less, the Ministry latest statistics show that in 2008 China's total cultivated area of $121700000 \mathrm{hm}^{2}$, the per capita share of cultivated land is only $0.093 \mathrm{hm}^{2}$, less than the world average of $40 \%$. More seriously, the country has 666 counties (districts) of arable land per capita is far below the FAO predetermined $0.053 \mathrm{hm}^{2}$ cordon, the situation is extremely severe. Land is a fundamental human survival, is the foundation of human development, in the massive root system of the tree of human life, the arable land is responsible for part of the nutrition lessons. Therefore, we can not deny the fact that human life is to get energy from planting activities, if there is no arable land, human beings can not survive. In the socio-economic activities, arable land resources has a unique role in the process of economic development, agricultural production, it is the most important means of production. Throughout the national economic system, the fundamental status of agriculture as the primary sector is strong unshakable. Only firmly adhere to this basic task, our country's economic development in order to stabilize orderly development of the country have adequate land resources and support.

\section{The Process of Urbanization of Land Acquisition and Farmland Protection Problems}

Extensive expansion of urban construction land, urban fringe farmland takes up a lot of quality, at the same time causing a serious waste of land, it has also led to declining arable land. Past small towns in the pursuit of extraordinary scale construction and development process, not too many people are concerned about the internal problems of urban construction, the country has built urban land use is not high performance, especially in the villages and towns where urbanization, as urban development not centralized, decentralized settlements, construction land per capita share of the generally higher. In addition, a large number of land has been expropriated, without accounting for many, unfinished projects, real estate development and deserted, abandoned industrial park, and no companies settled in the industrial area, not a long time to build towns, etc., which are a serious waste lot of land resources.

Urban construction land is extensive and serious waste, overall rural construction land extensive. According to the Ministry of Housing and Urban statistics, the degree of urban construction process of intensive use of land resources is very low, more than 1,700 county towns nearly 160 square meters of land per capita, while Zone widespread scattered layout, low intensity and land development low utilization problem. According to the special investigation department of land by the end of 2004, within the scope of the national urban planning idle, idle land and land grant but 
not for 260.26 million hectares, equivalent to $8 \%$ of the existing total urban land built-up areas.

Urbanization in the first performance of the development of the city center to the county as the center of the small town construction group is the focal point of our rapid development towns, focusing on the development of a certain size and strength of the center of towns, urban growth an echelon. But with the rapid development of urbanization, cities have been expanding, making farmland surrounding suburban counties continue to be occupied, the edge of town and suburban agricultural land to non-agricultural land conversion; and urban construction land expansion occurred in high quality land and the suitability of areas with better, resulting in a large number of high-quality agricultural land is occupied.

\section{Problems in Land Acquisition and Protection of Farmland in the Process of Urbanization}

Under China's current land management system, the local government is a relatively independent stake holders, often their only consider local economic development and short-term needs. Thus, inevitably lead to abuse of the power to approve, a large number of land acquisition and transfer of

land, these reasons lead to further land planning useless. Building needs depends on the supply of land, investment projects decided to issue the land use plan is very serious. At the same time, the legal status of the overall land use plan is not clear, on the strength of China's serious shortage of arable land protection planning breach or unauthorized modification plan to change the nature of land, non-agricultural construction, lack of clear punishment provisions.

Economic Development for the construction of urbanization played no small role, however, in recent years, it also appears many drawbacks we found, it in turn, many ways to Urbanization caused no small obstacle. Zone has a double edge structure and function of urban and rural areas, which also led to its complex and diverse types of land use, the use of structural disorder, various types of land intersect and interfere with each other. Especially in recent years, investment in economic development zone of overheating, resulting with the construction of development zones, residential areas, but also a large number of township enterprises quickly transferred to peri-urban areas, and in the long-term construction and the lack of rational planning and sufficient funds, then the original Some villagers mixed settlements and new urban development zones, residential areas, township enterprises, urban green space and the surrounding farming areas the situation will have a Chinese characteristics, which brings us to the problem is not easily resolved, is not conducive to saving land, but also to the further development of urban and rural areas create obstacles.

Responsible for some local governments in the planning of urban construction time like "generous", their pursuit of expanding the scale of investment in urban construction, created to develop urban construction situation, to achieve a large-scale investment to achieve a domestic regional the rapid development of GDP, in order to strive for excellence in performance. However, the "generous" urban construction does not necessarily give the local economy a big development, because with certain objective laws contrary to exceed the constraints of urban development support and resources and the environment. On the ideological level, we do not realize that having their living conditions among people close interdependence of the lack of development of urbanization concept of sustainable development, not understanding the true meaning of the scientific development concept. On the theoretical level, the analysis of urban construction and development planning, land size of just blindly pursue growth in the number, do not even do not consider the needs of future generations to realize the coordinated development of healthy and sustainable.

\section{Urbanization and Coordinated Development of Cultivated Land Resources}

Establish a standard land transfer market, to ensure farmers' land development rights. At present, land planning market is increasingly coming to the market, but in the process of land, it uses planning principals, roles, and create a plan by the external environment and are at the same time by the government supervisor in acting as. Meanwhile, the quick success of the blind and adjusts planning urban land use expansion excuse. Therefore, we must change the current land use situation, strengthening the urban land-use planning and management, strict planning approval process, strict 
qualification units work planning monitoring and evaluation. Construction Supervision System established with roughly the same use planning supervision system by the establishment of a neutral, impartial third party supervision and management unit, the production of land use planning in agriculture leadership and awareness will be constrained, at the same time, the quality of planning and must results to evaluate the effect of legal liability. Only in this way, the interests of landless peasants have hope in urban planning and construction of the real can be protected.

Improve the land preservation system, improve the basic farmland protection mechanism. Coordinated and sustainable socio-economic development, ecological security and food security is to implement the scientific concept of development, building a harmonious society, the question of meaning. This requires us to strictly enforce and implement the arable land and basic farmland protection system, a reasonable adjustment and reform according to the development of emerging issues; the implementation of arable land expropriation measures in accordance with the laws and regulations of land management, the overall plan for land use, urban master planning, village and town planning and the implementation of scientific management; land requisition compensation and resettlement system should continue to improve and increase investment in science and technology efforts, establish and improve the rational use of land conservation and income distribution system; responsible for the implementation of the principle of the protection of farmland and land management and other measures. Unreasonable to stop new construction land expansion, and gradually establish and industrialization, urbanization and agricultural modernization to adapt county farmland protection compensation system, and gradually increase the agricultural industry to support and nurture, guide and use of construction land compensation income of agriculture land, develop agricultural production. At the same time, we must further improve the basic farmland protection system. Governments at all levels to further strengthen the sense of responsibility in the protection of basic farmland, increase regulatory role of the central and provincial governments in terms of basic farmland protection, and strengthen the implementation of strong farmland protection target responsibility system; to establish a reasonable and timely supervision and inspection system, regularly or irregular tissue examination, basic farmland protection policies to the letter.

The development of land use planning, to develop new rural communities. Urbanization can promote rural population concentrated, intensive agricultural land, and therefore the development of urbanization has the potential to slow down the loss of arable land or even a substantial increase in arable land, which has been validated by the historical experience of developed countries. Urbanization process in China, a sharp decrease of arable land phenomenon of urbanization is one of insufficient development of the important reasons. Therefore, to protect the process of urbanization dynamic equilibrium of the total arable land, it is necessary to solve urbanization problems of this era is not sufficient.

Strengthen management, and effectively implement the land acquisition and benefit-sharing mechanisms. Land Expropriation Compensation is the most important issue, it is not just the question of land, it is economic issues, political issues, social issues, legal issues, and even cross-integration of these problems, China's land requisition system in urgent need of resolving the current a key problem. The basic guiding ideology developed countries and regions of the world taken by land requisition compensation system are: first, to follow market principles, to develop a reasonable compensation standards and projects. Second, the realization of land requisition compensation diversification. Third, the rational is allocation of land compensation fees. Fourth, the establishment of a land dispute arbitration mechanism.

\section{Conclusion}

In short, in order to promote sustainable development of the country and society, urbanization and agricultural land resources, coordination should be noted: Strengthening the intensive use of land, the rational allocation of land resources. Strictly control the amount of new construction land in Heilongjiang Province, scientific and rational development of all types of land the size of a standard, and strive to revitalize the stock of land, full use of space and high-level underground space, the maximum to avoid occupation of arable land; improve the city's comprehensive volume rate by 
urban renewal, play to the combined scale of urban land; when industrial-based urban planning, industrial construction will be concentrated as much as possible, to encourage the construction of multi-storey factory and can give certain preferential policies to motivate; to establish an effective incentive and restraint mechanisms to promote intensive land, idle land to increase the total cost of ownership, and promote the rational flow of the stock of land, to achieve extensive land use conversion to intensive land use. Strengthen arable land use system, to maintain the balance of total farmland. Continue to implement a strict system of balance of arable land, while improving balance evaluation system to ensure that does not reduce the amount of arable land, the quality does not decline. Actively promote the development and consolidation of land, pay attention to the development and utilization of cropland resources, increase the effective area of cultivated land and improve the quality of cultivated land. T Formulate preferential policies to encourage rural residents move to cities, to strengthen the settlements and idle air consolidation and development of agricultural land, increasing the number of arable land to achieve scale arable operations. Reduce the population pressure on arable land, so that the relative concentration of the dispersed arable land, cultivated land to achieve intensive management. At present, the rural residential land in Heilongjiang Province oversized widespread, land per capita level is much higher than the national standard of land, the pilot can homestead wards, namely its homestead farmers voluntarily replaced by a standard exchange for small towns homes, savings integrate rural land reclamation, both to improve the level of urbanization can achieve scale arable operations. Strengthen ecological environment, and improve the quality of cultivated land. Distribution of arable land in Heilongjiang Province has obvious geographical diversity law and arable land to complete the class, it should take advantage of the different climate and land type, based on the stable area of grain crops and actively cultivate new varieties of high-yield agriculture. To increase arable land ecological protection of capital investment, and gradually establish farmland ecological compensation, compensation of cultivated land resource consumption ecological compensation mechanism of cultivated land. Strengthen farmland ecological environment protection education, improve the existing laws and strengthen law enforcement, the introduction of farmland ecological safety regulations as soon as possible to ensure the coordinated development of urbanization and farmland resources.

\section{References}

[1] Cooper, T. Shine, T. McCann. 2006. An ecological basis for sustainable land use ofEastern Mauritanian wetlands [J]. Journal of Arid Environments, 67(1):116-141.

[2] Van Paassen, R.P. Roetter, H. Van Keulen, et al. 2007. Can computer models stimulatelearning about sustainable land use Experience with LUPAS in the humid (sub-) tropics of Asia [J]. Agricultural Systems, 94(3):874-887.

[3] A.J. Oskam, S. Feng. 2008. Sustainable land use under different institutional settings [J]. NJAS Wageningen Journal of Life Sciences, 55(4):295-306.

[4] Mustafa Omer. 2008. Energy, environment and sustainable development [J]. Renewable and Sustainable Energy Reviews, 12(9):2265-2300.

[5] Ackerman W V. 1999. Growth Control versus the Growth Machine in Redlands, California:Conflict in Urban Land Use [J]. Urban Geography, 20(2):146-167.

[6] Ademola K. Braimoh. 2009. Agricultural land-use change during economic reforms in Ghana [J]. Land Use Policy, 26(3):763-771. 